\title{
Research Article Epidemiological trend of COVID-19 in Nepal and the importance of social distancing to contain the virus
}

\author{
Amod K. Pokhrel 1,2,; Yadav P. Joshi ${ }^{3,4}$ and Sopnil Bhattarai ${ }^{5}$ \\ ${ }^{1}$ US-Nepal Policy Research Center, U.S.A._ORCID: 0000-0002-6478-7442 \\ ${ }^{2}$ Faculty of Science, Health \& Technology, Nepal Open University, Lalitpur, Nepal \\ ${ }^{3}$ Faculty of Science, Health \& Technology, Nepal Open University, Lalitpur, Nepal \\ ${ }^{4}$ Department of Public Health, Manmohan Memorial Institute of Health Sciences, Kathmandu, Nepal \\ E-mail: yadavjoshi@gmail.com, ORCID: 0000-0002-1578-9775 \\ ${ }^{5}$ Children's National Hospital, Washington, District of Columbia, U.S.A.; E-mail: sopnilb@gmail.com, ORCID: 0000-0001-8521-0661
}

Received: May 29, 2020; Accepted: June 14, 2020; Published: May 25, 2020

\begin{abstract}
There is limited information on the epidemiology and the effects of mitigation measures on the spread of COVID-19 in Nepal. Using publicly available databases, we analyzed the epidemiological trend, the people's movement trends at different intervals across different categories of places and evaluated implications of social mobility on COVID19. We also estimated the epidemic peak. As of June 9, 2020, Provinces 2 and 5 have most of the cases. People between 15 and 54 years are vulnerable to becoming infected, and more males than females are affected. The cases are growing exponentially. The growth rate of 0.13 and $>1$ reproduction numbers (R0) over time (median: 1.48 ; minimum: 0.58 , and maximum: 3.71) confirms this trend. The case doubling time is five days. Google's community mobility data suggest that people strictly followed social distancing measures for one month after the lockdown. By around the $4^{\text {th }}$ week of April, the individual's movement started rising, and social contacts increased. The number of cases peaked on May 12, with 83 confirmed cases in one day. The Susceptible-Exposed-Infectious-Removed (SEIR) model suggests that the epidemic will peak approximately on day 41 (July 21,2020 ), and start to plateau after day 80 . To contain the spread of the virus, people should maintain social distancing. The Government needs to continue active surveillance, more PCR-based testing, case detection, contact tracing, isolation, and quarantine. The Government should also provide financial support and safety-nets to the citizen to limit the impact of COVID-19.
\end{abstract}

Keywords: COVID-19, novel coronavirus ( $n$ CoV-2), reproduction number, SEIR model

सारांश: नेपालमा कोभिड-१९ को प्रसारण, प्रभाव र रोकथामका उपायहरुको वारेमा सीमित जानकारी रहेको पाइन्छा। यो अध्ययन नेपालमा कोभिड (१९ संग सम्बधित सार्वजनिक रूपमा उपलब्ध डाटाबेस र वेबसाईटहरूको प्रयोग गरेर भएको हो। यहाँ कोभिड-१९ को विभिन्न स्थानहरूमा समयको अन्तरालमा देखिएको प्रवृत्ति तथा मानिशहरुको सामाजिक गतिशीलता अनुसार कोभिड-१९ मा देखिएका प्रभावहरुको मूल्याकन गरिएको छ। साथै नेपालमा अधिकतम महामारीको अवधिको वारेमा पनि विश्लेषण गरिएको छ। जून ९, २०२० सम्म, प्रदेश नं २ र $y$ मा धेरै बिरामिहरु देखिएका छन्। १५ देखि $y \gamma$ वर्षका व्यक्तिहरू कोभिड-१९ वाट हुने संक्रमणको उच्च जोखिममा छन् । महिला भन्दा पुरुषहरू बढ़ी प्रभावित भएका छन् । नेपालमा कोभिड-१९ का बिरामीहरु संख्या बढिरहेका छ। कोभिड-१९ को वृद्धि दर ०.१३, र समयसंगै प्रजनन संख्या $\left(\mathrm{R}_{0}\right)$ को मान 9 भन्दा बढ़ (मध्यस्थ: १. ४६; न्यूनतमः ०.५६, र अधिकतम: ३.७१) रहेको छ। जसले कोभिड-१९ को संक्रमण हुने प्रवृत्तिलाई पुष्टि गर्दछा बिरामीहरु दोब्बर हुने अन्तराल पाँच दिनको रहेको छ। Google's community mobility data को अनुसार, मानिसहरुले लकडाउनको एक महिना सम्म कडाईकासाथ सामाजिक दूरी कायम गरिएको देखियो। अप्रिलको तेस्रो हप्ता देखि मानिसहरुको हिड्ने ऋम र सामाजिक सम्पर्क बढिरहेको देखिएको छ। दोश्रो अधिकतम संक्रमण मे १२ मा भएको देखिन्छ। उक्त मितिमा द३ वटा कोभिड-१९ नया विरामीहरु पुष्टि भएका थिए । Susceptible-Exposed-Infectious-Removed (SEIR) मोडेलका अनुसार, लगभग ४१ दिनमा (जुलाई २१, २०२०) संक्रमण अधिकतम हुनेछ र यो ५० दिन सम्म कायम रहीरहनेछ। नोभेल कोरोनाभाइरस $(\mathrm{nCoV}-2)$ को प्रसारण रोक्नका लागि सामाजिक दूरी कायम गर्नु अनिवार्य छ। सरकारले सक्रिय निगरानी, पीसीआर-आधारित परीक्षण, केसपत्ता लगाउने (case detection), कन्ट्याक्ट ट्रैसिंग (contact tracing) गर्ने, कोभिड-१९ का विरामीहरु लाइ अलगगौ राखने isolation) र क्वारेन्टाइनको संख्या बढाउने जस्ता उपायहरु लाइ निरन्तरता दिनु आवश्यक छा कोभिड-१९ को प्रभाव लाइ नियन्त्रण गर्न सरकारले नागरिकहरुलाई वित्तीय सहायता प्रदान गर्नुका साथै र जन चेतना जगाउनु आवश्यक देखिन्छ।

\footnotetext{
*Corresponding author, E-mail: amodpokhrel@gmail.com; Tel.: +1-510-847-1243

(c) RECAST/TU
} 


\section{Introduction}

COVID-19 is a disease caused by the novel coronavirus (nCoV-2) that spreads rapidly from person to person. It was officially reported on December 31, 2019, in Wuhan, Hubei Province, People's Republic of China (Li et al., 2020), and subsequently spread to many other countries with asynchronous patterns. On January 30, 2020, the outbreak was declared a Public Health Emergency of International Concern. On March 11, the World Health Organization (WHO) categorized it as a pandemic. A few weeks later, it affected over 100 countries (Remuzzi 2020).

As of June 9, 2020, there are about 7,237,093 cases around the world, and that 411,444 people have died worldwide due to COVID-19. In South Asia or SAARC region, which comprises of Nepal, India, Pakistan, Bangladesh, Bhutan, Sri Lanka, Maldives, and Afghanistan, the total confirmed COVID-19 cases have reached 301,395 , which is $4 \%$ of the total global confirmed cases.

The earliest appearance of COVID-19 in Nepal was on January 24, 2020, in a 32-year-old Nepalese student of Wuhan University of Technology, Wuhan, China, who returned home on January 13 with no previous history of comorbidities (Bastola et al., 2020). After that, the second case was confirmed on March 23 in a 19-year-old female Nepali student. She had traveled to Nepal from France via Qatar on March 17. In the response of a total of about two COVID-19 positive cases, the Government of Nepal $(\mathrm{GoN})$ imposed the first lockdown on March 23 to contain the spread of the coronavirus. Afterward, the infection started to increase rapidly, mostly in the provinces where districts are bordering with India, (NDRRMA, 2020a).

The GoN has implemented a series of directives concerning extraordinary interventions and public health guidelines to contain the virus. The stringent measures include lockdown, social distancing, and the shutdown of industrial and commercial activities. The schools and offices are also closed, and flights (domestic and international) have been canceled. Despite these measures, the number of confirmed cases is rising. Therefore, it is crucial to know if the actions taken are working, and if so, to what extent? Information, such as the people's movement, social interactions, the case growth rate, and doubling time, can help assess the situation and plan the steps needed to be taken to contain the spread of the virus. Besides, the quantification and assessment of transmissibility, such as the basic reproduction number $\left(\mathrm{R}_{0}\right)$, could help design the public health responses. The $\mathrm{R}_{0}$ is the average number of secondary cases caused by the primary infected case. Many countries and public health agencies have used the $\mathrm{R}_{0}$ to understand infection transmission dynamics, design the responses, and assess intervention strategies (Bjørnstad, 2018; Yan et al., 2020; Mandal et al., 2020). The $\mathrm{R}_{0}$ number also helps to understand the required vaccination coverage to contain the disease or infection (Bjørnstad, 2018). The ideal $R_{0}$ is less than one. The $\mathrm{R}_{0}<1$ suggests that the pathogen will be unsuccessful in invading the population and causing an epidemic or pandemic. The $\mathrm{R}_{0}$ values changes after the introduction of control measures; therefore, estimation of $R_{0}$ in real-time or $R$ can help assess the transmission dynamics (Cori et al. 2013).

This paper aims to analyze the trend of COVID19 cases in Nepal and report the situation in terms of the epidemic curve, overall case growth rate, case doubling (or halving) time, and the time-varying reproduction number $(\mathrm{R})$. It also aims to forecast the progression of the COVID-19 epidemic. Moreover, it reports the people's movement trends over time across different categories of places such as retail and recreation, groceries and pharmacies, parks, transit stations, workplaces, and residential areas, and its impact on driving up the COVID-19 cases.

\section{Materials and Methods}

\subsection{Data}

The trend analysis included data from January 24 to June 9, 2020, obtained from publicly available databases and websites. The primary sources of data included the Center for Systems Science and Engineering (CSSE) at Johns Hopkins University (CSSE, 2020), Google's Community Mobility Reports on individual movement trend (Google, 2020), the data from National Disaster Risk Reduction and Management Authority (NDRRMA), Ministry of Home Affairs, Government of Nepal (NDRRMA 2020b); and Wikipedia (Wikipedia, 2020).

\subsection{Individual's movement trend}

We used Google's Nepal Community Mobility data (on people's movement) to see how strictly people followed the shelter-in-place or social distancing measures. Google uses smartphone location data to publish reports about people's movement in an area. The mobility data are collected from Google users who have turned on the location history setting.

\subsection{Epidemic curve}

The epidemic curve indicates the number of new cases over time (incidence). It was calculated (and visualized) using the CSSE (CSSE, 2020) and NDRRMA (NDRRMA, 2020b) database. 


\subsection{Case growth trend}

\subsubsection{General trend}

To evaluate the COVID-19 case trend, the full data set was divided into pre- and post-lockdown subsets with a cut-off date of March 23, 2020. Then the post-lockdown data were analyzed to see if the cases are growing faster or slower than linearly (Figure 5). For this, a smooth trend line (using linear regression method) was plotted on the postlockdown cumulative number of COVID-19 cases.

\subsubsection{Exponential trend}

A simple log-linear (exponential) model of the form $\log (\mathrm{y})=\mathrm{r} * \mathrm{t}+\mathrm{b}$ was used to assess the incidence (exponential trend) of COVID-19 cases. In the model, $y$ is the incidence, $r$ (the slope) is the growth rate, $t$ is the number of days since the start of case reporting, and $b$ is the intercept. The value of $r$ was used to estimate the doubling or halving time of the epidemic.

\subsection{Case doubling time}

The case growth rate and the doubling time of COVID-19 cases were estimated for two time periods: between March 23 and May 01, when strict social distancing was observed, and between May 01 and June 09, when increased individuals mobilities were seen (Table 1).

\subsection{The time-varying reproduction number $(R)$}

The method proposed by Cori et al. (2013) was used to estimate the $\mathrm{R}$ from the available incidence data. The serial distribution intervals are the time between the onset of symptoms in a primary case. The start of symptoms in secondary cases is a critical input for determining the $\mathrm{R}$. To compute the serial interval, 3.96 days (95\% CI 3.53-4.39 days) and SD 4.75 days (95\% CI 4.46-5.07 days) were used, as reported by $\mathrm{Du}$ et al. (2020). Similar approaches have been used by other authors to estimate $\mathrm{R}$ and to forecast the epidemic of COVID-19 (Mahmud, 2020).

\subsection{Forecasting}

We used the deterministic compartment (mathematical) model-Susceptible-ExposedInfectious-Removed (SEIR) (Bjørnstad, 2018) to estimate the spread of infection and forecast COVID-19 epidemic in Nepal. The dynamics of SEIR model can be described as ordinary differential equation (ODE) model, described by the following equation:

$\mathrm{dS} / \mathrm{dt}=\mathrm{mu}-\mathrm{S} *($ beta $* \mathrm{I}+\mathrm{mu})$

$\mathrm{dE} / \mathrm{dt}=\mathrm{dE}=$ beta $* \mathrm{~S} * \mathrm{I}-\mathrm{E} *($ sigma $+\mathrm{mu})$

$\mathrm{dI} / \mathrm{dt}=\mathrm{dI}=\operatorname{sigma} * \mathrm{E}-\mathrm{I} *($ gamma $+\mathrm{mu})$
$\mathrm{dR} / \mathrm{dt}=\mathrm{dR}=$ gamma $* \mathrm{I}-\mathrm{mu} * \mathrm{R}$

-mu: Death rate (per day).

- beta: The transmission rate. Reproduction number (R).

- sigma: The infection rate. The rate at which an exposed person becomes infective. The average duration of incubation (latency).

- gamma: The durations of infectiousness or the recovery rate. The average duration

- of infection determines the recovery rate.

- $S$ : The susceptible individual but not infected at time t. This is the total at-risk population, who may contract the COVID-19.

-E: Number of populations exposed to viruses or infected but not yet infectious.

-I: Number of infected individuals who can spread the disease through contact with susceptible

- R: Number of recovered individuals, who have gained the immunity or died due to the disease.

-N: Nepal's total estimated population in 2020.

\subsection{Model assumptions}

We made the following assumptions and set the parameters for the model:

- The population $>15$ years is susceptible (based on the current trend seen in Nepal).

- The population is of a constant size.

- $\mathrm{mu}=[(0.0064 \times 29071791) /(29071791 \times 365)]^{1}$

- beta (Reproduction number or $\mathrm{R})=$ coefficient of infection: 1.48 (median)

- sigma=coefficient of latency: $1 / 5.2$ days or 0.19 (Li, 2020)

- gamma $=$ coefficient of recovery rate $=1 / 14.5=$ 0.07 (Kramer, 2020)

- $\mathrm{S}=$ population $>15$ years in Nepal $(29071791 *$

$0.70=20059536)$ (Statista, 2020)

$-\mathrm{S}$ rate $=(20059536 / 29071791=0.69)$

- $\mathrm{E}=$ number of people tested for COVID-19 until

June 09, $2020=272,489$ (Kramer, 2020)

$-\mathrm{E}$ rate $=(272,489 / 29071791=0.00937)$

-I= 4068 until June 09, 2020

- I rate $=(4068 / 29071791=0.00013993)$

$\bullet \mathrm{R}=689$ (recovered:674 + death:15)

$-\mathrm{R}$ rate $=(689 / 29071791=0.0000237)$

All data were analyzed and visualized using the $\mathrm{R}$ software ( $\mathrm{R}$ Core Team, 2020) and the following packages: tidyverse, ggplot2, tidy-covid19, incidence, magrittr, lubridate, EpiEstim, gridExtra, kableExtra, ggforce, dSolve. Microsoft Excel including the Microsoft Excel spreadsheet provided by Cori et al. (2013) was used to estimate the time varying reproduction number.

The "deSolve" package in $\mathrm{R}$ ( $\mathrm{R}$ Core Team, 2020) was used to solve SEIR ordinary differential 1 Death rate, crude (per 1,000 people) in Nepal was reported at
6.404 in 2017, according to the World Bank 
equations (ODE). The time ' 0 ' on the SEIR model is June 10,2020 and time '90' is September 08, 2020.

\section{Results}

\subsection{COVID-19 cases in Nepal}

The first COVID-19 case was recorded on January 24, 2020, in Kathmandu. Since then, the cumulative and daily new confirmed cases are rising. Figure 1 and 1.1. show the trend, and the number of cumulative and new confirmed cases. The blue lines are smoothed conditional means, and the grey bands on them are the $95 \%$ confidence interval.
3.2. COVID-19 cases by geographic location and, age, and sex in Nepal

As of June 09, 2020, there are 4068 active cases in 72 districts. Of the total cases, $584(14 \%)$ individuals have been recovered. Out of the total 77 districts, Kapilvastu and Rautahat have the highest number of active cases, 406 (18\%) and 323 (14\%). Both districts share a border with India. Moreover, most cases are confined in province 2 and 5 (Figure 2).

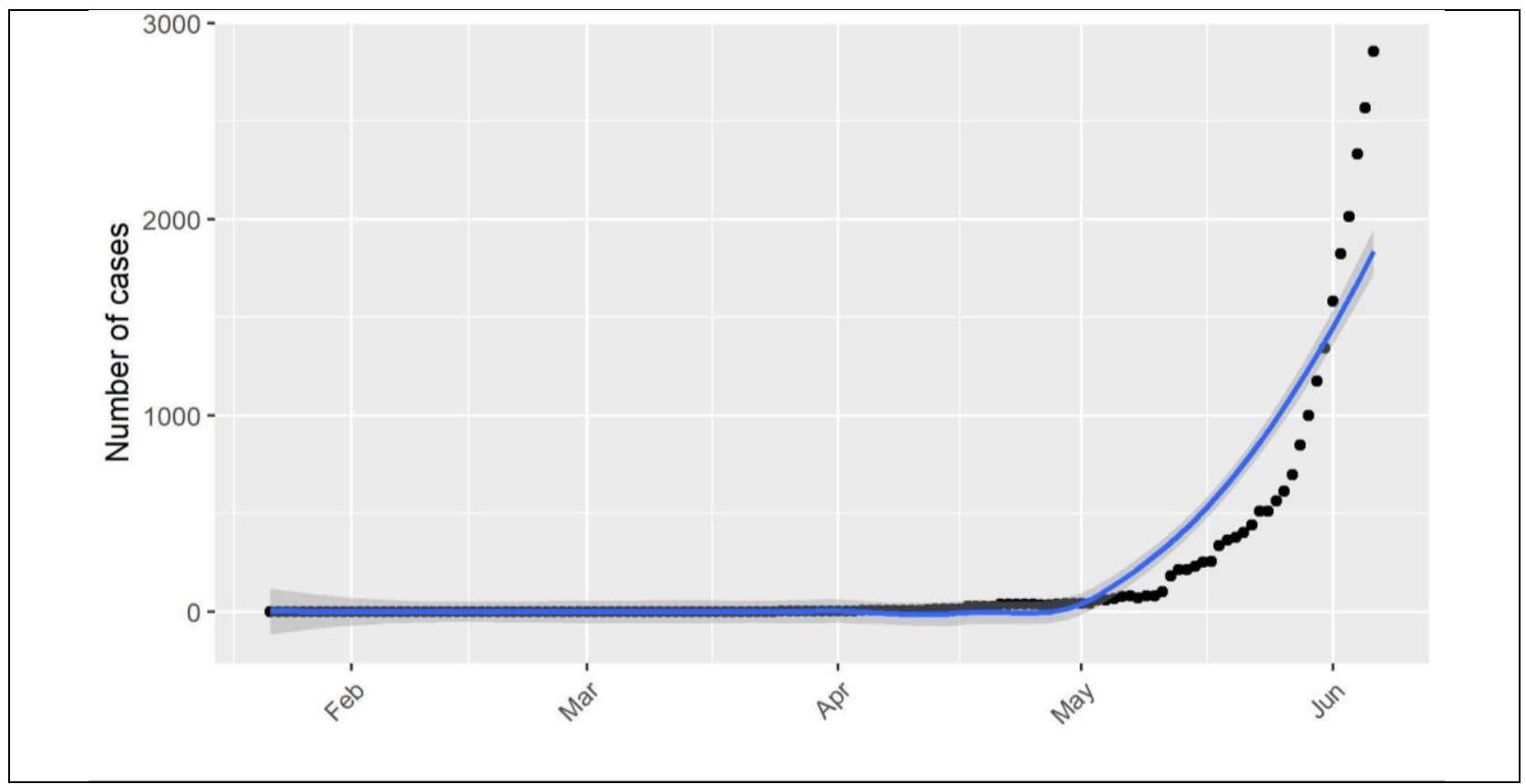

Figure 1. Current cumulative confirmed cases in Nepal

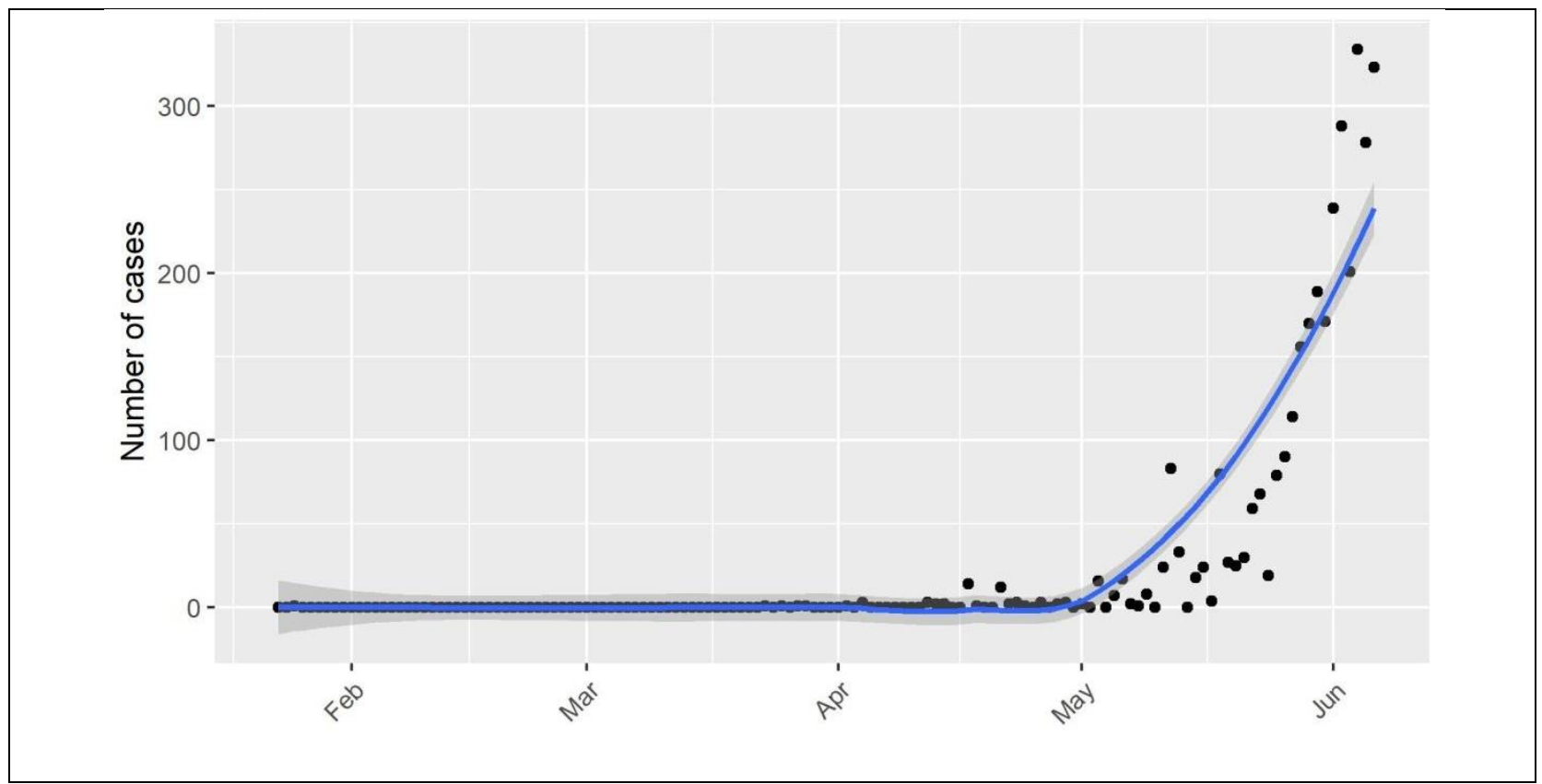

Figure 1.1. Daily new confirmed cases in Nepal 


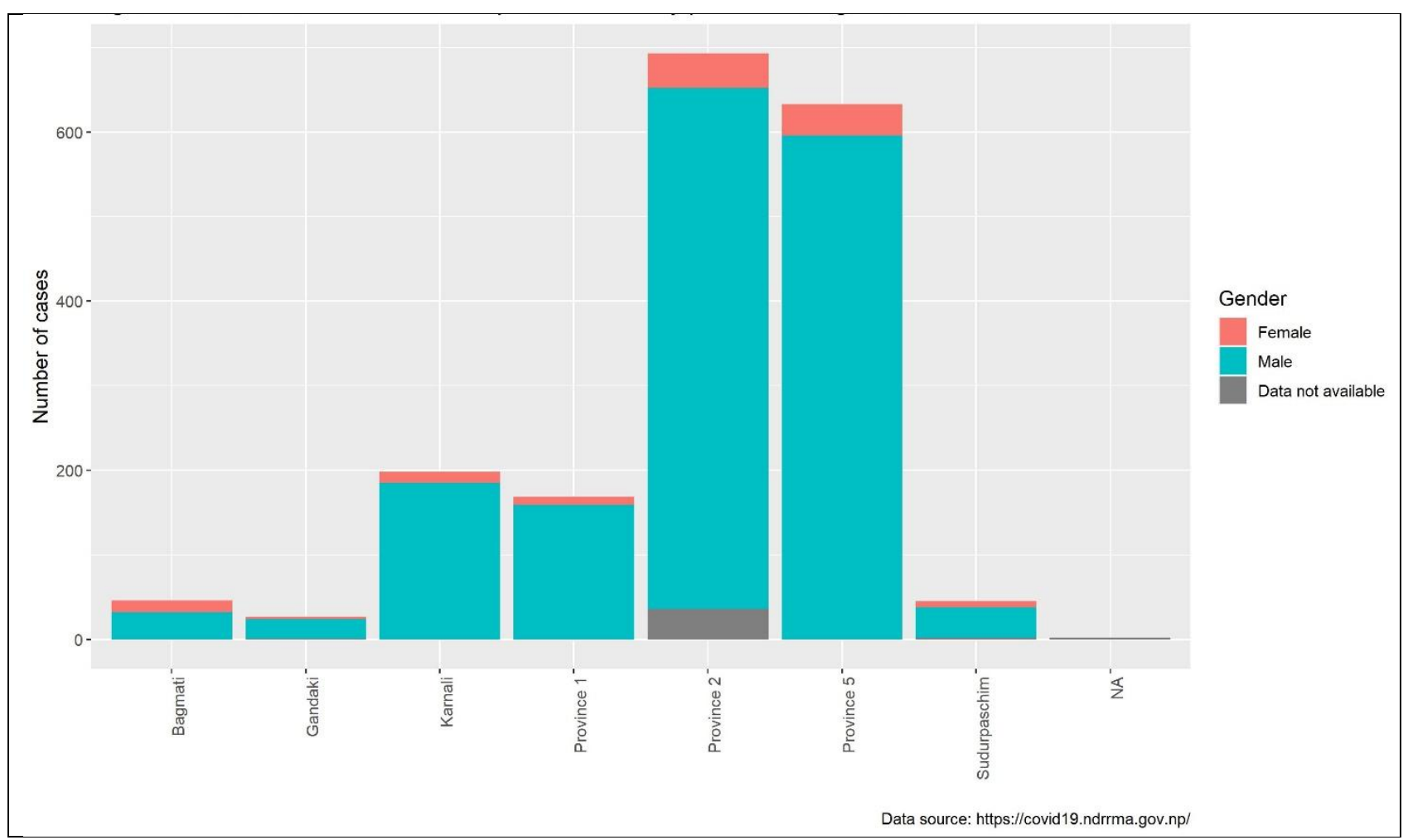

Figure 2. Distribution of SARS-COV2 positive cases by province and gender

3.3. Government's intervention to contain the virus and people's response

On March 23, the Government of Nepal (GoN) declared the country-wide lockdown. The analysis of Google's community mobility data suggests that people strictly followed the shelter-in-place and social distancing measures. They spent more time in the home. Visits to grocery stores, pharmacies and workplaces dropped dramatically. However, around the 4th week of April, individuals' outdoor movement started to increase (Figure 3).

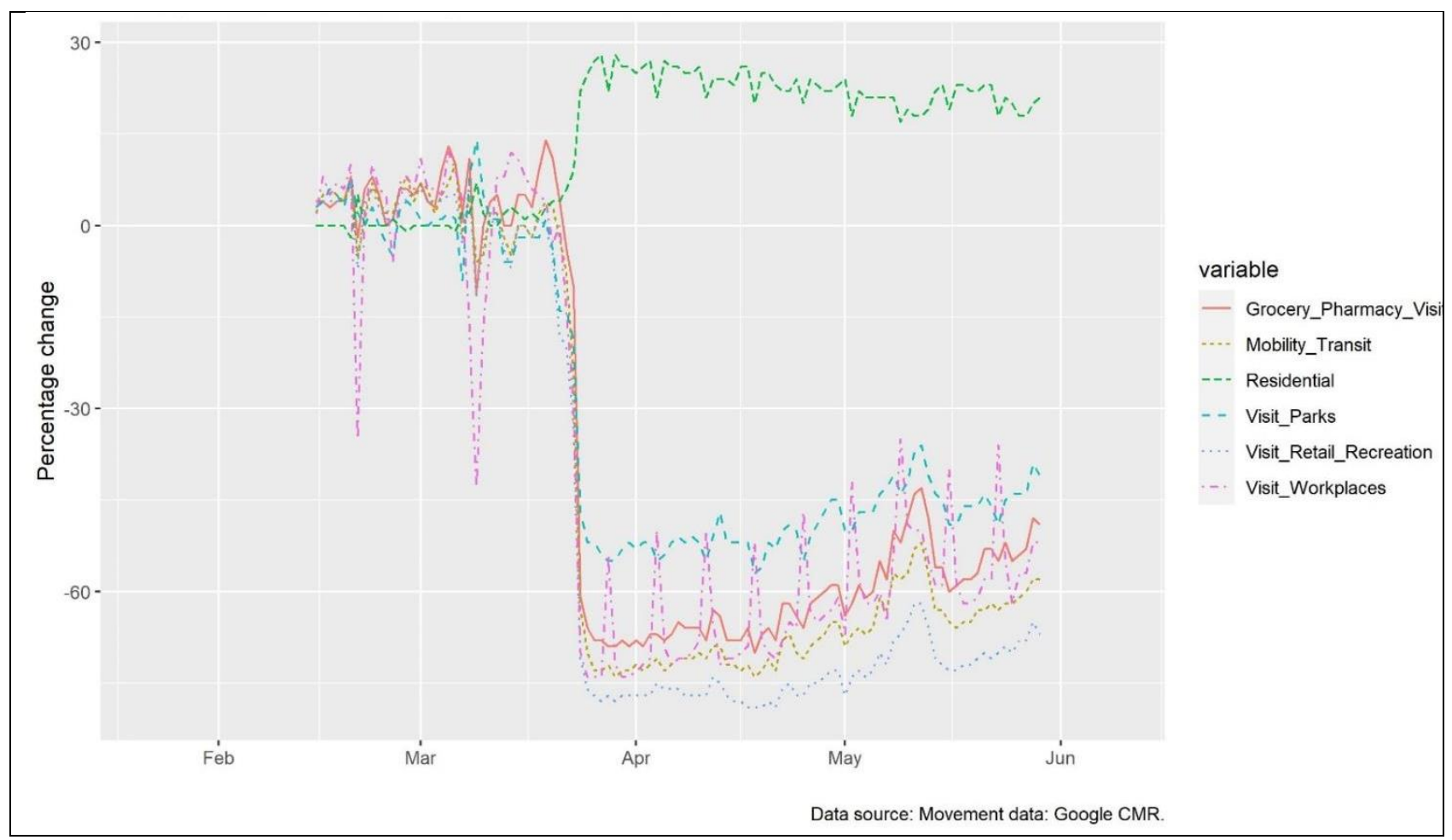

Figure 3. Percentage change in individual behaviors (\% change relative to the baseline period 01/03/2020-2/06/2020) 


\subsection{The COVID-19 trend over time and after the lockdown}

The data show that cases were slowly picking up after the lockdown, but there was an exponential growth after individuals' outdoor movement started to increase in May (Figure 4). The second wave of epidemic peaked on May 12, with 83 confirmed cases in one day.

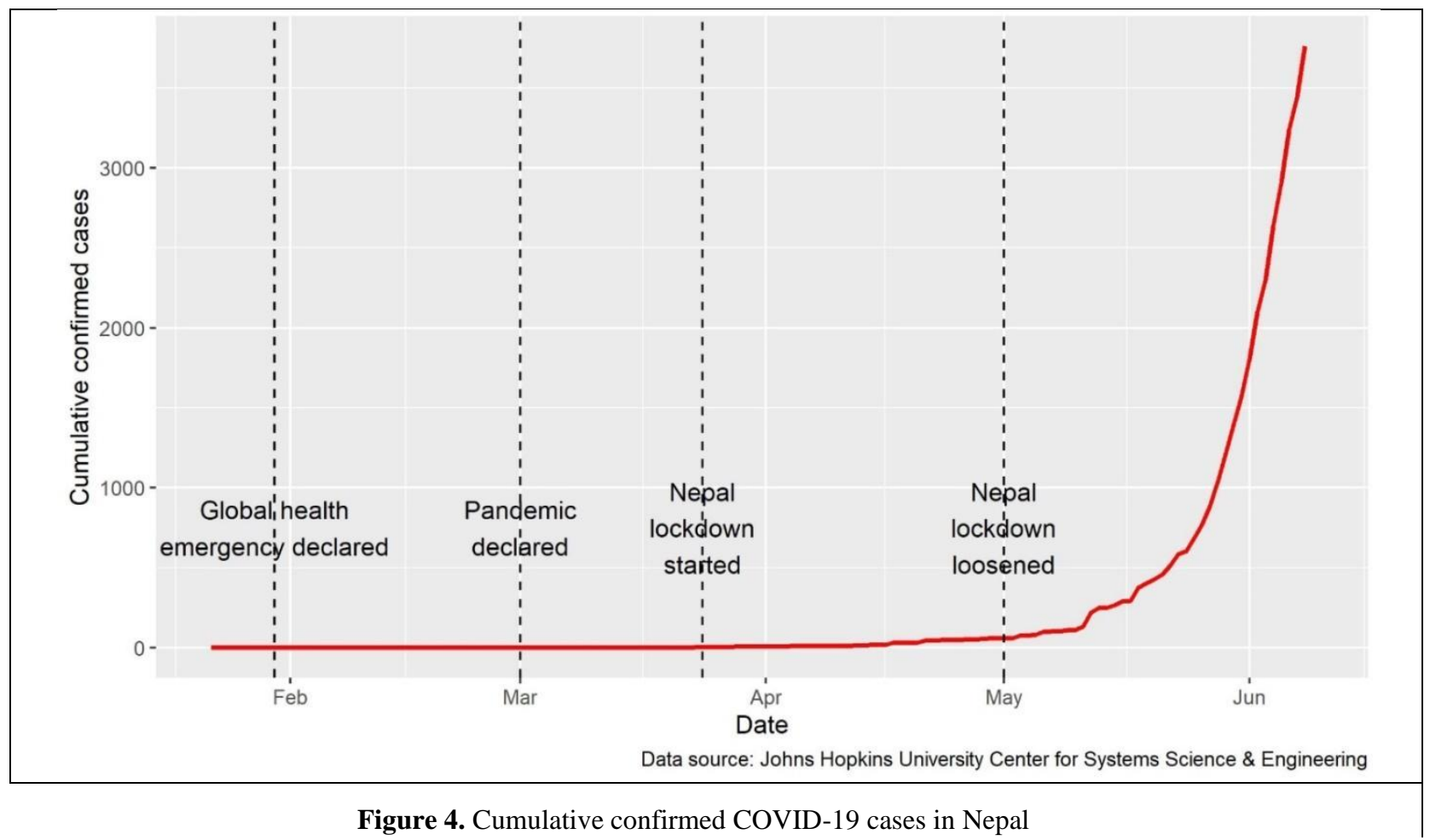

The current growth rate of COVID-19 cases in Nepal is higher than linear (Figure 5), which means it is growing exponentially (Figure 6).

There could be several reasons for the rise in COVID-19 cases. The three principal reasons could be connected to the Nepalese returning from countries affected by COVID-19, an increase in the rate of testing, and increased mobility of people, or loosening restrictions.

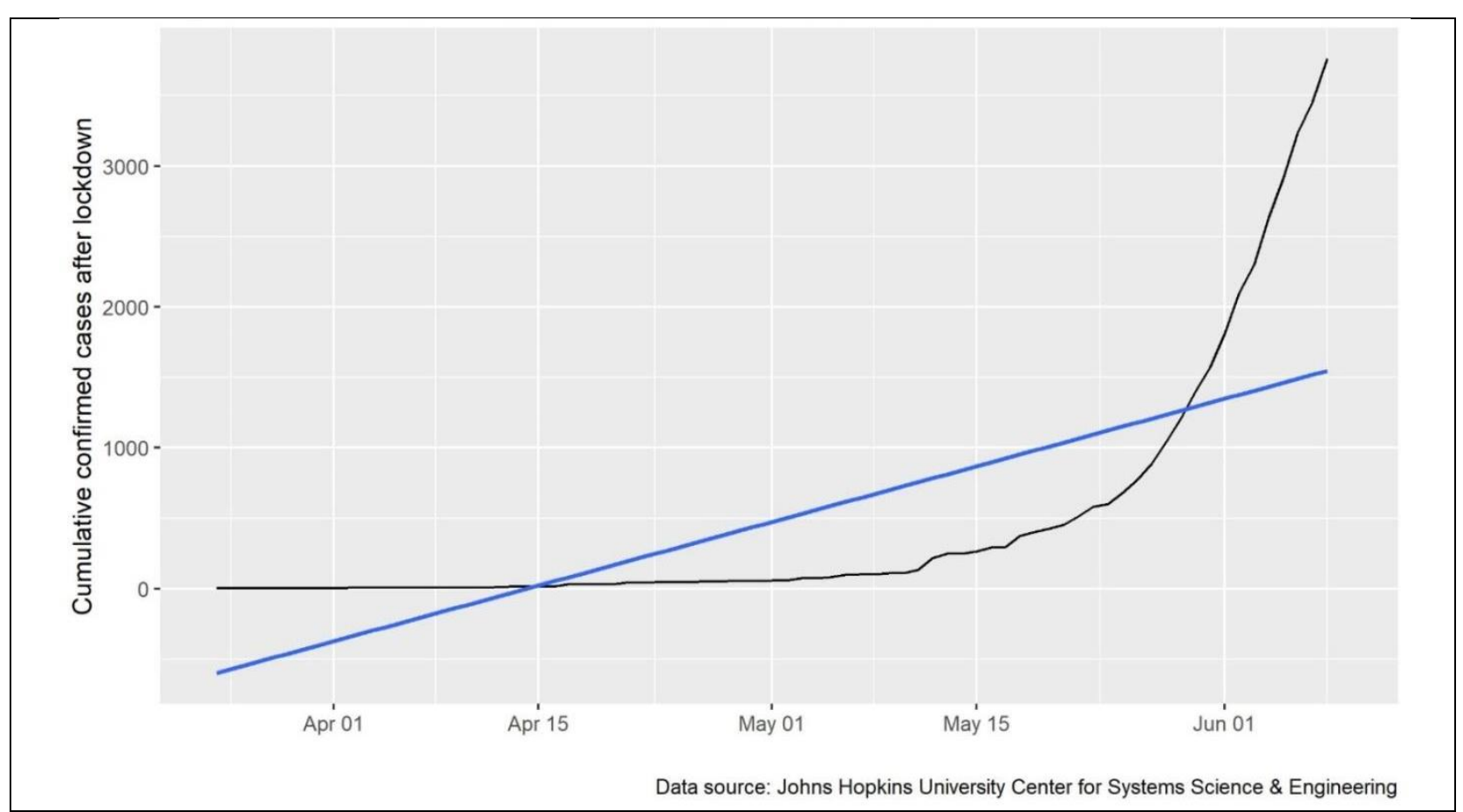


Figure 5. Cumulative confirmed COVID-19 cases after lockdown

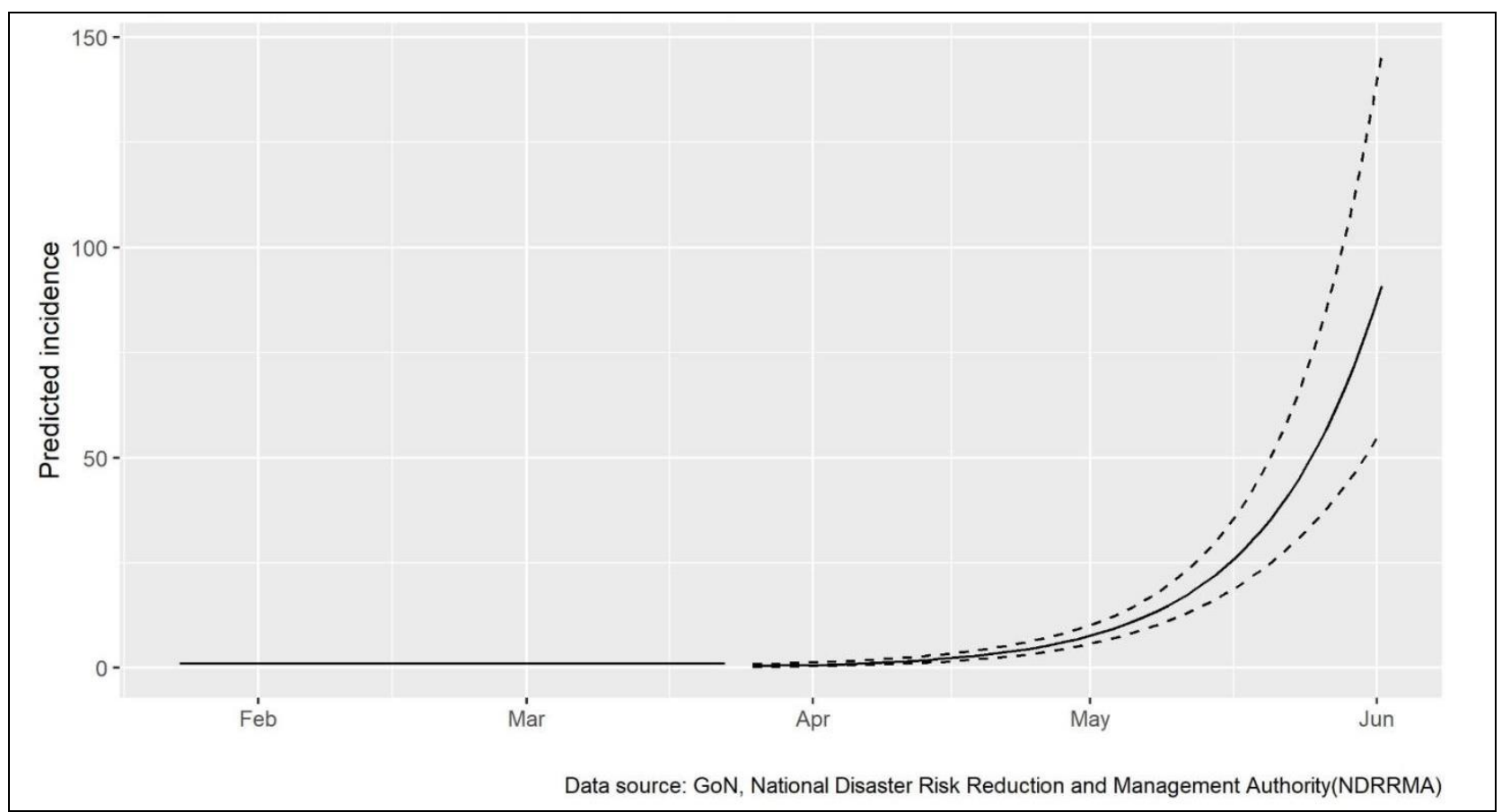

Figure 6. COVID-19 daily incident cases in Nepal. Exponential growth of case after end of March, 2020

\subsection{COVID-19 case growth rate and doubling time}

Figures 7 and 7.1 show the growth trend for two time periods: between March 23 and May 01, when strict social distancing was observed, and between May 01 and June 09, when increased individuals mobilities were seen (Google mobility data). Table 1 shows the estimated growth rate and doubling times.

During the time window, when people strictly followed social distancing (March 23 and May 01), the case growth rate and doubling time were 0.03 and about 22 days. The growth rate jumped to 0.13 , and the doubling time reduced to 5 days between May 01 and June 09, when individuals' mobility increased, as seen in Figure $\mathbf{4}$ above.

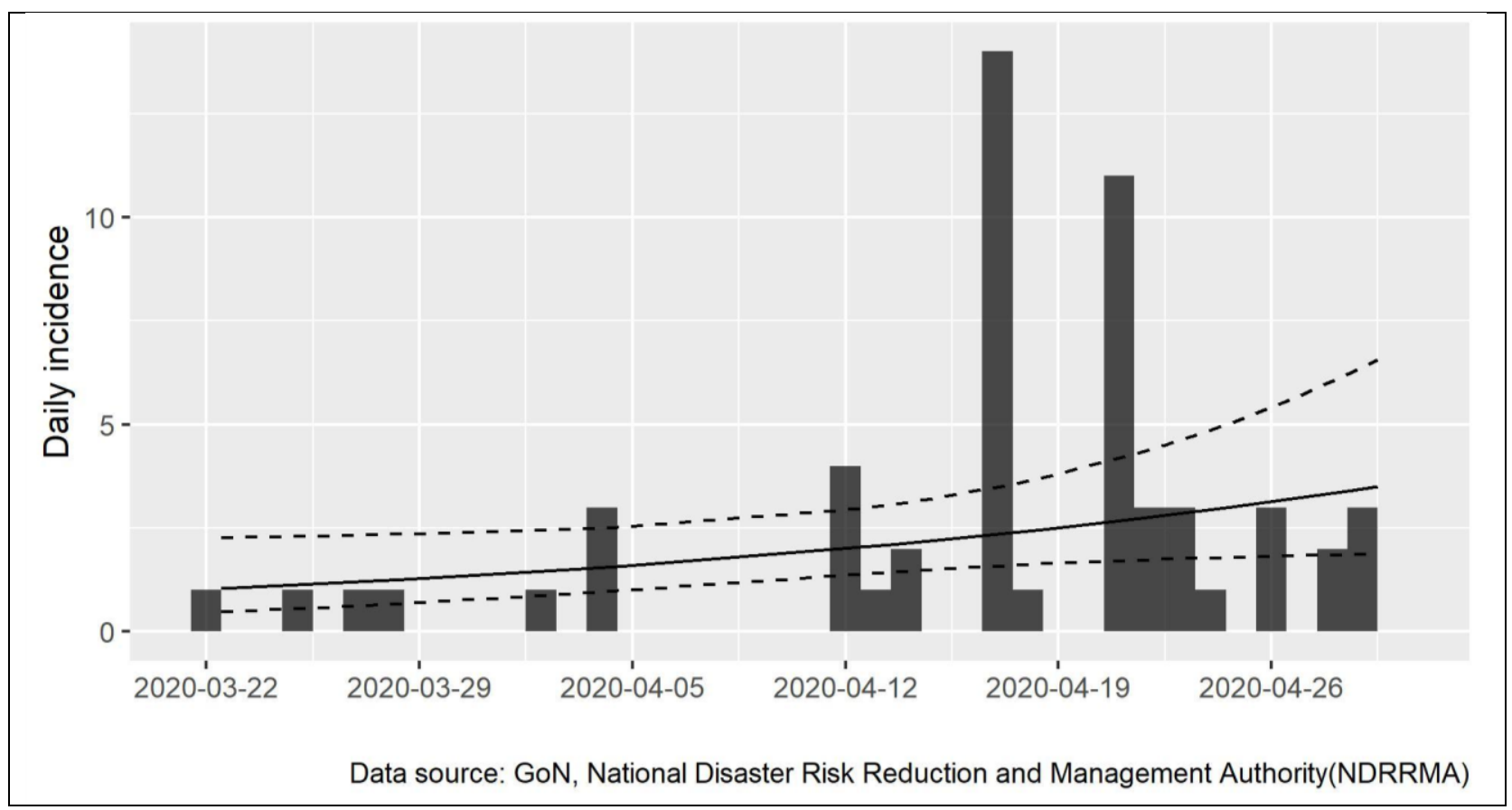

Figure 7. COVID-19 Growth rate in Nepal between 03/23 and 05/0102020 in long regression model 


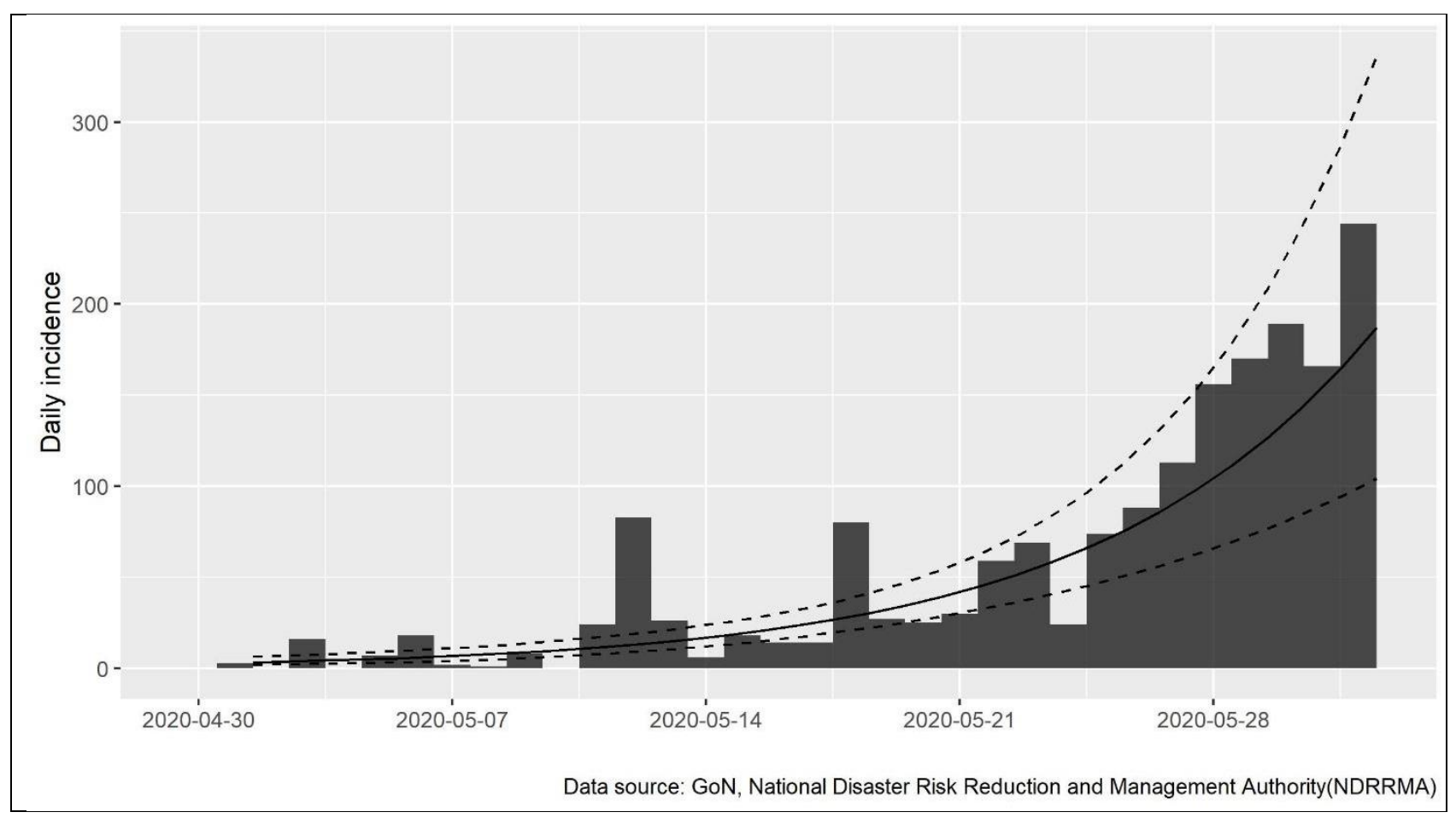

Figure 7.1. COVID-19 growth rate in Nepal between 05/01/2020 and 06/09/2020 in long regression model

Table 1. COVID-19 infection forecast for two scenarios

\begin{tabular}{cll}
\hline \multicolumn{1}{c}{ Duration } & \multicolumn{1}{c}{$\begin{array}{c}\text { Growth rate (r) (95\% } \\
\text { CI) }\end{array}$} & Doubling time in days (95\% CI) \\
\hline $03 / 23 . / 2020$ to $05 / 01 / 2020$ & $0.03(0.0008-0.0629)$ & $22(11-847)$ \\
$05 / 01 / 2020$ to $06 / 09 / 2020$ & $0.13(0.095-0.165)$ & $5(4.21-7.27)$ \\
\hline
\end{tabular}

Table 2. COVID-19 infection forecast for two scenarios

\begin{tabular}{ll}
\hline \multicolumn{1}{c}{ Infection mode } & \multicolumn{1}{c}{ R or Beta= 1.48 } \\
\hline Infection peak & Day 41- July 20, 2020 \\
Infection plateau & Day 80- August 29, 2020 \\
Infection subside & Day 90- September 08, 2020 \\
\hline
\end{tabular}




\subsection{The Effective Reproduction Number (R)}

The effective reproduction number $(\mathrm{R})$ is useful to assess how well public health interventions are working. Figure 8 shows the estimated $\mathrm{R}$ values over 78 days (March 24-June 01, 2020). The overall median R-value is 1.48 (SD:0.21), with a minimum of 0.58 and a maximum of 3.71, respectively. The median $\mathrm{R}$-value of 1.48 suggests the outbreak is not yet under control. The R pattern in Figure 8 also shows a possible "second wave," but there are not enough cases to make a reliable assessment.

\subsection{Forecast of COVID-19 epidemic in Nepal}

3.7.1. Forecast assuming beta or reproduction number as 1.48

The SEIR model suggests that if the reproduction number remains at 1.48 , then the epidemic will peak approximately on day $41-$ July 21, 2020, and infect about $12 \%$ of the population. The infection will plateau in approximately 80 days (Table 2 and Figure 9).

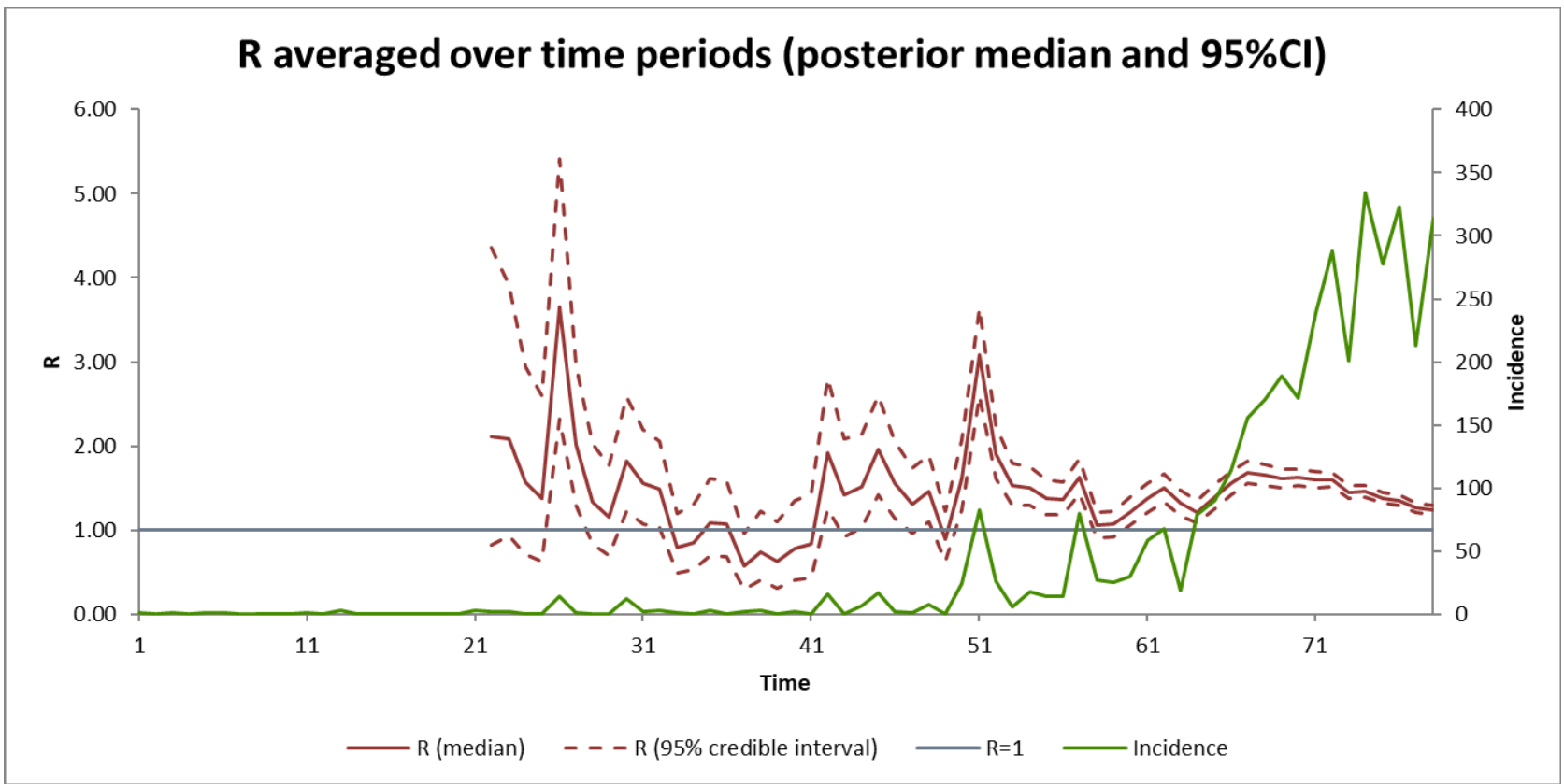

Figure 8. Effective reproduction of COVID-19 in Nepal

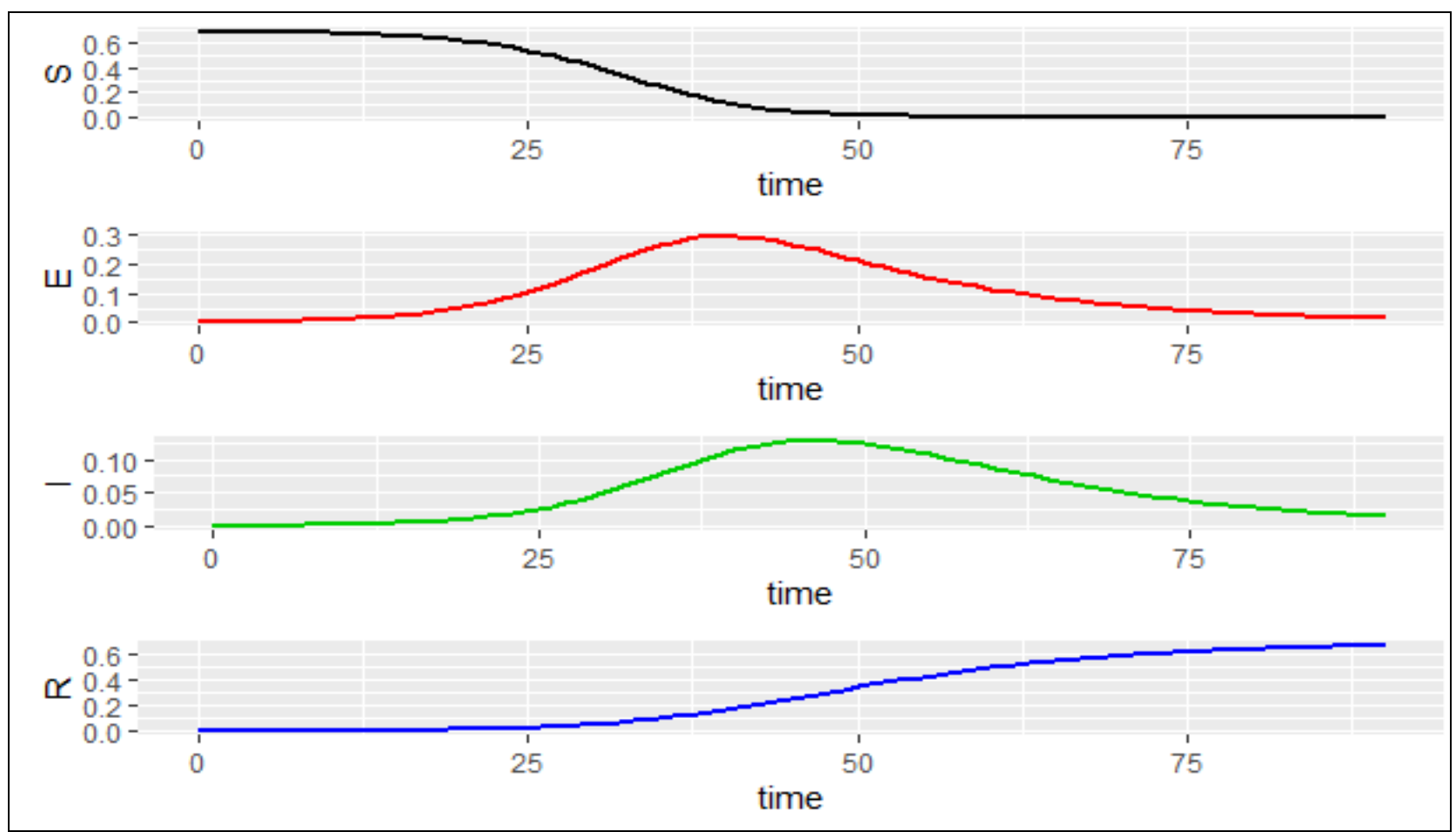

Figure 9. Forecast of COVID-19 epidemic in Nepal with $\mathrm{R}=1.48$ 


\section{Discussion}

The analysis of publicly available data suggests that the growth rate of COVID-19 cases in Nepal is higher than linear, which means it is growing exponentially. The exponential growth trend indicates that Nepal has not contained the virus yet. The observed higher reproduction number and lower-case doubling time further confirms this trend. Google's community mobility data suggest that people strictly followed social distancing measures for one month. But after that, the individual's movement started rising, and social contacts increased. The second wave of epidemic peaked on May 12, with 83 confirmed cases in one day. The SEIR model forecasts that the COVID-19 epidemic will peak approximately on day 41- July 20,2020 and start to plateau after day 80. If the strict virus containment measures are not taken, then there is a chance that $12 \%$ of susceptible people could be infected.

At present, the GoN is using rapid diagnostic antibody test kits (R.D.T.) to diagnose COVID-19 cases. Until now, the GoN has tested about 272,489 people (Worldometer, 2020). To compare these numbers, the Indian Government has tested 4,916,116 people (Worldometer, 2020). 'In both countries, most of the tests have been conducted using R.D.T. There are no publicly available data on the sensitivity and specificity of R.D.T. being used in Nepal. Variation of results of R.D.T. kits has been observed in many countries. Therefore, there is a possibility that R.D.T. could be missing many positive cases in Nepal.

The reverse transcription-polymerase chain reaction (rRT-PCR) is considered the gold standard of COVID-19 (SARS-COV2) detection. In some Indian states, people who tested positive in the rRTPCR have been found negative in the rapid test. In the state of Rajasthan, the correlation of results between rRT-PCR and rapid tests was $5.4 \%$. Ideally, it should be $90 \%$. Considering lower sensitivity, the Indian Council of Medical Research had once advised all states to halt the R.D.T-based testing for some time (Dey and Bagchi 2020). Compared with RT-PCR, the sensitivity and specificity of the R.D.T. are low. Therefore, it would be prudent to consider verifying and validating the accuracy of rapid test kits being deployed in many parts of the country.

There are many significant limitations to the present study and analysis. These are mainly related to assumptions used due to the scarcity of epidemiological data such as reproduction number and details on contact tracing from Nepal. This model could be refined with actual $\mathrm{R}$ values obtained from the contact tracing data being collected in Nepal.

\section{Conclusions}

At present, there is no vaccine and promising drugs available to prevent or treat the COVID-19. Therefore, prevention is the best option we have, which can be done by breaking the transmission chain of the virus. The containment of the virus requires extraordinary efforts, trust, and cooperation from the Government and citizens. It also requires regional and international cooperation and assistance. To contain the spread of the virus and protect people from COVID-19, the Nepal government needs to continue shelter-in-place orders for some time, and increase active surveillance, more PCR based testing, case detection, contact tracing, isolation, and quarantine activities. The public health agencies and academic institutes in Nepal could also use the statistical and mathematical models to assess the situation and identify the strategies to control the spread of the virus and disease.

Prolongation of lockdown or shelter-in-place will cause severe economic loss to people, businesses, and industries. Therefore, the Government should consider introducing an economic stimulus package to provide safety nets to the citizens and small and medium enterprises. Citizens also need to support and cooperate by strictly following the social distancing measures to halt the spread of the virus.

Acknowledgments: This study is part of the USNepal Policy Research Center's Nepal COVID-19 watch project. The US-NPRC is the US-based policy research center $((501)(C)(3)$ registered nonprofit organization). This project aims to track the COVID-19 situation in Nepal and apply basic modeling to determine the policy response. We are thankful for the support provided by the entire executive committee of the US-NPRC for this study. This work would not have been possible without the encouragement of Dr. Surendra R. Devkota, the advisor to US-NPRC; Dr. Rajan Pant, the President of US-NPRC; Dr. Suman Parajuli, the General Secretary of US-NPRC; Mr. Tarun Paudel, Spokesperson of US-NPRC; and Dr. Ramesh Pant, and Mr. Rajendra Raut, members of US-NPRC. 
Authors Contributions: A.K.P conceived of and designed the study, gathered, analyzed, and interpreted data, and drafted the manuscript. Y.P.J. further collected data and reviewed the manuscript. S.B. critically reviewed the manuscript.

Conflicts of Interest: The authors declare no conflicts of interest.

Funding: No funding was sought or obtained to conduct this study.

\section{References}

Bastola A, Sah R, Rodriguez-Morales AJ, Lal BK, Jha R, Ojha HC, Shrestha B, Chu DK, Poon LL, Costello A, Morita K. The first 2019 novel coronavirus case in Nepal. The Lancet Infectious Diseases. 2020 Mar 1;20(3):279-280. DOI:https://doi.org/10.1016/S1473-3099(20)30067-0

Bjørnstad ON. Epidemics: models and data using R. Springer; 2018 Oct 30.

Cori A, Ferguson NM, Fraser C, Cauchemez S. A new framework and software to estimate time-varying reproduction numbers during epidemics. American journal of epidemiology. 2013 Nov 1;178(9):1505-1512. DOI: 10.1093/aje/kwt133

CSSE. Mapping COVID-19, Systems Science and Engineering (CSSE) at Johns Hopkins University. 2020 [cited 2020 05/15/2020]; Available from: https://systems.jhu.edu/research/public-health/ncov/.

Dey, S and Bagchi, I. Rajasthan stops rapid tests, ICMR asks other states to pause. The Times of India 2020 [cited 2020 04/22/2020]; Available from: http://timesofindia.indiatimes.com/articleshow/75283005.c ms?utm_source=contentofinterest\&utm_medium=text\&utm campaign $=$ cppst.

Du Z, Xu X, Wu Y, Wang L, Cowling BJ, Meyers LA. Serial interval of COVID-19 among publicly reported confirmed cases. Emerging infectious diseases. 2020 Jun;26(6):13411343. DOI: $10.3201 /$ eid2606.200357

Google. COVID-19 Community Mobility Reports. See how your community is moving around differently due to COVID-19. 2020 [cited 2020 05/19/2020]; Available from: https://www.google.com/covid19/mobility/

Kraemer MU, Yang CH, Gutierrez B, Wu CH, Klein B, Pigott DM, Du Plessis L, Faria NR, Li R, Hanage WP, Brownstein JS. The effect of human mobility and control measures on the COVID-19 epidemic in China. Science. 2020 May 1;368(6490):493-497. DOI: 10.1126/science.abb4218

Li Q, Guan X, Wu P, Wang X, Zhou L, Tong Y, Ren R, Leung KS, Lau EH, Wong JY, Xing $X$. Early transmission dynamics in Wuhan, China, of novel coronavirus-infected pneumonia. New England Journal of Medicine. 2020 Jan 29 382(13): 1199-1207. DOI:10.1056/nejmoa2001316

Mahmud A, Lim PY. Applying the SEIR Model in Forecasting The COVID-19 Trend in Malaysia: A Preliminary Study. medRxiv. 2020 Jan 1. DOI: 10.1101/2020.04.14.20065607

Mandal M, Jana S, Nandi SK, Khatua A, Adak S, Kar TK. A model based study on the dynamics of COVID-19: Prediction and control. Chaos, Solitons \& Fractals. 2020 May 13:109889. DOI: 10.1016/j.chaos.2020.109889

NDRRMA. National Disaster Risk Reduction and Management Authority 2020a [cited 202014 May 2020. ]; Available from: https://covid19.ndrrma.gov.np/.

NDRRMA. National Disaster Risk Reduction and Management Authority (NDRRMA), Ministry of Home Affairs, Nepal 2020 b [cited 2020 05/13/2020 ]; Available from: https://covid19.ndrrma.gov.np/.

$\mathrm{R}$ Core Team. A language and environment for statistical computing. 2020, R Foundation for Statistical Computing: Vienna, Austria.

Remuzzi A, Remuzzi G. COVID-19 and Italy: what next?. The Lancet. 2020 Mar 13. 395(10231): 1225-1228.DOI: 10.1016/S0140-6736(20)30627-9

Statista Nepal. Age distribution from 2008 to 2018. 2020 [cited $2020 \quad 05 / 19 / 2020] ; \quad$ Available from: https://www.statista.com/statistics/422727/age-distributionin-nepal/.

Wikipedia. COVID-19 pandemic in Nepal. 2020 [cited 2020 05/19/2020]; Available from:

https://en.wikipedia.org/wiki/COVID-

19_pandemic_in_Nepal.

Worldometers. COVID-19 Coronavirus Pandemic. 2020 [cited 2020 05/19/2020]; Available from:

https://www.worldometers.info/coronavirus/?utm_campaign =homeAdUOA?Si

Yan Y, Shin WI, Pang YX, Meng Y, Lai J, You C, Zhao H, Lester E, Wu T, Pang CH. The first 75 days of novel coronavirus (SARS-CoV-2) outbreak: Recent advances, prevention, and treatment. International journal of environmental research and public health. 2020 Jan;17(7):2323. DOI: 10.3390/ijerph17072323 